Volume 10 Nomor 2, April 2019, p.034-039.

Faculty of Law, Universitas Kristen Maranatha

ISSN: 2085-9945 I e-ISSN: 2579-3520

Nationally Accredited Journal by SINTA

\title{
Pentingnya Merek Bagi Pelaku Usaha Mikro, Kecil dan Menengah Di Jawa Barat
}

1. Rika Ratna Permata,

\section{Tasya Safiranita Ramli,}

\section{Biondy Utama}

Faculty of Law, Padjajaran University

tasya_safiranita@yahoo.com

Submitted: 2018-12-17; Reviewed: 2019-04-10; Accepted: 2019-04-30

\begin{abstract}
At this time, trade mark was a competing to build a brand. The reason is that the more positive the image of a brand in the community, the brand will affect the level of people's purchases of the brand. Brand is one of the factors that people consider to buy a product or service. Generally people tend to buy products that enter the top level in a brand survey. Building a brand is not an easy effort, it takes effort and capital that is not small in order to build a strong image in the community. It would be very unfair if the brand that had been built was copied by an irresponsible business actor. Business actors need a legal protection for the brand they have built to avoid fraudulent actions that lead to fraud business competition. Brand legal institutions are made to provide protection for a brand that is affixed to an item or service that is traded. These institutions provide exclusive rights for brand holders to use the brand.
\end{abstract}

Keywords: Brand; Business; Protection

\section{PENDAHULUAN}

Usaha mikro kecil menengah (UMKM) memegang peran penting bagi perekonomian ASEAN. Sebab, 96 persen ekonomi ASEAN berasal dari UMKM. ${ }^{1}$ industri UMKM

\footnotetext{
${ }^{1}$ https://www.merdeka.com/uang/presiden-jokowi-sebut-umkm-kunci-pertumbuhan-ekonomiasean.html
} 
Volume 10 Nomor 2, April 2019

juga sangat membantu masyarakat dengan membuka lapangan pekerjaan, dimana total di seluruh Indonesia terdapat 62 juta UMKM yang memperkejakan 116 juta orang. Peranan Usaha Mikro, Kecil, dan Menengah(UMKM) di perekonomian nasional terhitung cukup besar. Jumlah tersebut mencapai 99,9 persen dan penyerapan tenaga kerja mencapai 97 persen.

Salah satu kunci keberhasilan dalam menjalankan UMKM adalah branding. Brand image atau brand description, yakni deskripsi tentang asosiasi dan keyakinan konsumen terhadap merek tertentu. ${ }^{2}$ Menurut Kotler, brand image ialah persepsi dan keyakinan yang dilakukan oleh konsumen, seperti tercermin dalam asosiasi yang terjadi dalam memori konsumen. ${ }^{3}$

Dewasa ini pelaku usaha berlomba-lomba membangun sebuah brand. Alasannya adalah semakin positif citra sebuah brand di masyarakat maka brand tersebut akan mempengaruhi tingkat pembelian masyarakat terhadap brand tersebut. Menurut Robert Brauneis, ${ }^{4}$ Brand (cap) merupakan konsep pemasaran (marketing) yang terdiri dari tanda atau cap dan asosiasi konsumen pada cap tersebut. Brand menjadi salah satu faktor pertimbangan masyarakat untuk membeli suatu produk barang atau jasa. Untuk melihat bagaimana citra brand di masyarakat, diadakanlah suatu survey oleh suatu lembaga ${ }^{5}$ yang nantinya dapat menjadi ukuran yang dapat dipegang oleh masyarakat maupun pelaku usaha. Umumnya masyarakat cenderung membeli produk yang masuk ke dalam tingkatan teratas dalam suatu survey brand.

Membangun sebuah brand bukanlah usaha yang mudah, diperlukan usaha maupun modal yang tidak sedikit demi membangun citra yang kuat dalam masyarakat. Akan menjadi sangat tidak adil bila brand yang telah dibangun dengan susah payah ditiru oleh pelaku usaha yang tidak bertanggung jawab. Pelaku usaha membutuhkan sebuah perlindungan hukum atas brand yang telah dibangunnya agar terhindar dari perbuatan curang yang mengarah ke persaingan usaha curang.

Pranata hukum merek dibuat untuk memberikan perlindungan atas suatu brand yang ditempelkan pada suatu barang atau jasa yang diperdagangkan. Pranata tersebut memberikan hak eksklusif bagi pemegang merek dalam menggunakan brand tersebut. Hak eksklusif adalah hak yang melekat kepada pencipta, pemilik merek,

\footnotetext{
${ }^{2}$ Santoso, S., \& Tjiptono, F., Riset Pemasaran Konsep dan Aplikasi dengan SPSS, Jakarta: Alex Media Komputindo, hlm. 49

${ }^{3}$ Kotler, P., \& Keller, K.L., Manajemen Pemasaran Jilid I, Edisi 12, Jakarta: Indeks Kelompok Gramedia, Hlm. 346

${ }^{4}$ Robert Brauneis, US Trademark Law, bahan ajar pada Pelatihan dalam Rangka Kerjasama Masyarakat Uni Eropa dan Asia di Bidang Hak Kekayaan Intelektual, Jerman, Desember, 2005, hlm. 1-8 Sebagaimana dikutip oleh Rahmi Jened, Kata Generik" adalah syarat absolut tidak dapat didaftar sebagai merek, MEDIA HKI., Vol.X/No. 1/Januari 2013, hlm. 1

${ }^{5}$ Contohnya survey yang dilakukan oleh Top Brand. Survey ini sudah dilakukan selama 14 tahun, dipublikasikan di media dan dipergunakan oleh banyak perusahaan maupun sebagai data pendukung mahasiswa untuk study-nya. Bahkan hasil survei ini kerap dikutip dalam makalah-makalah dan jurnal ilmiah serta pernah dipresentasikan di University of New South Wales di Australia.
} 
Volume 10 Nomor 2, April 2019

penemu berupa hak moral dan hak ekonomi sehingga memerlukan perlindungan hukum. ${ }^{6}$ Untuk memperoleh hak eksklusif tersebut pemilik brand harus menempuh prosedur pendaftaran merek dan juga brand tersebut harus memenuhi syarat-syarat agar dapat didaftar sebagai merek.

\section{PEMBAHASAN}

Merek merupakan suatu tanda yang diterapkan terhadap produk barang, jasa yang dipergunakan untuk perdagangan barang dan/atau jasa. Dalam suatu merek terdapat 3 hal yang harus diperhatikan yaitu: tanda sebagai daya pembeda yang membedakan suatu produk dengan produk lainnya, kedua, barang dan jasa, dimana merek itu harus diterapkan kepada barang dan jasa tertentu, yang ketiga, merek tersebut harus dipergunakan dalam perdagangan barang dan/atau jasa.

Fungsi merek adalah untuk membedakan barang dan/atau jasa yang diproduksi oleh orang atau badan hukum dalam kegiatan perdagangan barang dan/atau jasa. Rachmadi Usman ${ }^{7}$ menyatakan bahwa fungsi merek adalah sebagai pembeda dari produk barang dan jasa yang dibuat oleh seseorang atau badan hukum lain. Barang atau jasa tersebut perlu diberi tanda pengenal untuk membedakannya. Juga bagi pihak produsen adalah sebagai jaminan nilai hasil produksinya, khususnya mengenai kualitas, kemudahan pemakaiannya, sedangkan bagi pedagang, merek digunakan untuk promosi barang dagangannya guna mencari dan meluaskan pasaran.

Sedangkan untuk pihak konsumen merek diperlukan untuk mengadakan pilihan barang yang akan dibeli. Singkatnya fungsi merek adalah sebagai tanda pembeda, jaminan kualitas, dan aset yang berharga. ${ }^{8}$

Berikut 10 alasan pentingnya merek bagi UKM: ${ }^{9}$

1. Brand menempel di Ingatan

2. Brand adalah aset

3. Brand menggugah sisi emosional konsumen

4. Brand menciptakan totalitas pada layanan usaha

5. Brand memudahkan pelanggan menemukan bisnis kita

6. Brand menciptakan kepribadian

7. Brand memiliki kekuatan untuk menarik konsumen

8. Brand akan menghemat biaya usaha

9. Brand mempengaruhi perilaku pembelian

10. Brand dan personal branding saling terkait

\footnotetext{
${ }^{6}$ Rika Ratna Permata, Hukum Mererk dan Dilusi Merek di Jepang dan Amerika Serikat, bandung, CV Global Sinergi Indonesia, hlm. 12.

${ }^{7}$ Rachmadi Usman, Hukum Hak atas Kekayaan Intelektual, Bandung: Alumni, hlm. 320.

${ }^{8}$ Paul L.C. Torremans (ed.), Intellectual Property and Human Rights, United Kingdom, Kluwer Law International, hlm. 385.

${ }^{9} \mathrm{http}: / /$ entrepreneur.bisnis.com/read/20140124/258/199196/ini-10-alasan-pentingnya-brand-bagi-ukm
} 
Volume 10 Nomor 2, April 2019

Pendaftaran merek di Indonesia menganut sistem konstitutif. Dalam sistem konstitutif, hak atas merek baru akan timbul ketika merek telah didaftarkan. Dalam sistem ini pendaftaran adalah suatu keharusan. ${ }^{10}$ Hal tersebut diatur dalam Pasal 3 Undang-Undang Nomor 20 Tahun 2016 tentang Merek dan Indikasi Geografis yaitu: "Hak atas merek diperoleh setelah merek tersebut terdaftar".

Menurut para ahli sistem konstitutif lebih memberikan kepastian hukum dibandingkan sistem deklaratif. ${ }^{11}$ Emmy Pangaribuan dalam hal ini berpendapat bahwa sistem konstitutif lebih memberi kepastian hukum mengenai hak atas merek kepada seseorang yang telah mendaftarkan mereknya itu. Sudargo Gautama juga sependapat dengan Emmy Pangaribuan bahwa sistem konstitutif lebih memberikan kepastian hukum. ${ }^{12}$

Sebuah merek agar dapat didaftarkan maka harus memenuhi syarat-syarat agar merek tersebut dapat didaftarkan. Pasal 20 Undang-Undang Nomor 20 Tahun 2016 tentang Merek dan Indikasi Geografis mengatur syarat-syarat apa saja yang menyebabkan merek tidak dapat didaftar yaitu:

a. bertentangan dengan ideologi negara,peraturan perundang-undangan, moralitas,

b. agama, kesusilaan, atau ketertiban umum;

c. sama dengan, berkaitan dengan, atau hanya menyebut barang dan/atau jasa yang dimohonkan pendaftarannya;

d. memuat unsur yang dapat menyesatkan masyarakat tentang asal, kualitas, jenis, ukuran, macam, tujuan penggunaan barang dan/atau jasa yang dimohonkan pendaftarannya atau merupakan nama varietas tanaman yang dilindungi untuk barang dan/atau jasa yang sejenis;

e. memuat keterangan yang tidak sesuai dengan kualitas, manfaat, atau khasiat dari barang dan/atau jasa yang diproduksi;

f. tidak memiliki daya pembeda; dan/atau

g. merupakan nama umum dan/atau lambang milik umum.

Pasal 21 Ayat (1) Undang-Undang Nomor 20 Tahun 2016 tentang Merek dan Indikasi Geografis memuat ketentuan mengenai penolakan pendafataran merek yaitu permohonan ditolak jika merek tersebut mempunyai persamaan pada pokoknya atau keseluruhannya dengan:

a. merek terdaftar milik pihak lain atau dimohonkan lebih dahulu oleh pihak lain untuk barang dan/atau jasa sejenis;

\footnotetext{
${ }^{10}$ H. OK. Saidin, Aspek Hukum Hak Kekayaan Intelektual, Jakarta: PT. RajaGrafindo Persada, 2015, hlm. 359.

${ }^{11}$ Sistem ini tidak mewajibkan adanya suatu pendaftaran merek untuk mendapatkan suatu hak atas merek.

${ }^{12}$ H. OK. Saidin, op cit, hlm. 475
} 
Volume 10 Nomor 2, April 2019

b. merek terkenal milik pihak lain untuk barang dan/atau jasa sejenis;

c. merek terkenal milik pihak lain untuk barang dan/atau jasa tidak sejenis yang memenuhi persyaratan tertentu; atau

d. Indikasi Geografis terdaftar.

Selain hal-hal tersebut di atas, permohonan juga ditolak jika merek tersebut melanggar ketentuan Pasal 21 Ayat (2) Undang-Undang Nomor 20 Tahun 2016 yaitu:

a. merupakan atau menyerupai nama atau singkatan nama orang terkenal, foto, atau nama badan hukum yang dimiliki orang lain, kecuali atas persetujuan tertulis dari yang berhak;

b. merupakan tiruan atau menyerupai nama atau singkatan nama, bendera, lambang atau simbol atau emblem suatu negara, atau lembaga nasional maupun internasional, kecuali atas persetujuan tertulis dari pihak yang berwenang; atau

c. merupakan tiruan atau menyerupai tanda atau cap atau stempel resmi yang digunakan oleh negara atau lembaga Pemerintah, kecuali atas persetujuan tertulis dari pihak yang berwenang.

Berdasarkan ketentuan Pasal 21 Ayat (3) Undang-Undang Nomor 20 Tahun 2016 tentang Merek dan Indikasi Geografis, Permohonan ditolak jika diajukan oleh Pemohon yang beriktikad tidak baik.

\section{KESIMPULAN}

Berdasarkan pembahasan di atas, dapat disimpulkan bahwa merek penting bagi UMKM karena sebagai representasi dari produk barang yang dihasilkan. Sehingga merek tersebut perlu didaftarkan untuk mendapatkan perlindungan terhadap hak eksklusif berupa hak ekonomi dan moral juga untuk kepastian hukum dalam hal pihak ketiga mempergunakan mereknya tanpa izin.

Dalam penelitian ini, penulis juga menyarankan bahwa diperlukan sosialisasi atau penyuluhan hukum mengenai pentingnya merek untuk meningkatkan kesadaran hukum pelaku UMKM sehingga dapat meningkatkan daya saing dan perekonomian Bangsa Indonesia dalam perdagangan bebas.

\section{DAFTAR PUSTAKA}

\section{Buku}

H. OK. Saidin, Aspek Hukum Hak Kekayaan Intelektual, Jakarta: RajaGrafindo Persada, 2015.

Kotler, P., \& Keller, K.L., Manajemen Pemasaran Jilid I, Edisi 12, Jakarta: Indeks Kelompok Gramedia. 
Dialogia luridica: Jurnal Hukum Bisnis dan Investasi

Volume 10 Nomor 2, April 2019

Paul L.C. Torremans (ed.), Intellectual Property and Human Rights, United Kingdom, Kluwer Law International.

Rachmadi Usman, Hukum Hak atas Kekayaan Intelektual, Bandung: Alumni, 2003.

Rika Ratna Permata, Hukum Mererk dan Dilusi Merek di Jepang dan Amerika Serikat, Bandung, CV Global Sinergi Indonesia.

Santoso, S., \& Tjiptono, F., Riset Pemasaran Konsep dan Aplikasi dengan SPSS, Jakarta, PT. Alex Media Komputindo.

\section{Sumber Lain}

https://www.merdeka.com/uang/presiden-jokowi-sebut-umkm-kunci-pertumbuhanekonomi-asean.html

http://entrepreneur.bisnis.com/read/20140124/258/199196/ini-10-alasan-pentingnyabrand-bagi-ukm 